\title{
Os jovens, a web e a dinâmica relacional ${ }^{1}$ \\ Young people, web and relational dynamics
}

\section{Elci Candido Ferreira Marcilio}

Professora da rede pública municipal de São Caetano do Sul; mestranda em Comunicação, pela Universidade Municipal de São Caetano do Sul - USCS.

E-mail: elciferreira@uscs.edu.br

O livro Como a web transforma o mundo insere-se como mais uma obra relevante quando tanto se discute hoje o papel da $w e b$, das redes sociais e de novas dinâmicas nas relações da sociedade da informação. Os autores são franceses e especialistas em novas tecnologias: Francis Pisani (francispisani.net) é blogueiro do Monde.fr, e seu blog Transnets.net é dos mais influentes; Dominique Piotet dirige a filial norte-americana do L'Atelier, órgão dedicado às novas tecnologias do BNP Paribas.

A primeira parte do livro apresenta-se em três capítulos: "Os jovens e a web, juntos nas nuvens"; "Sobre a dinâmica relacional" e "As técnicas discretas da web de hoje". Todos tratam sobre o imenso sucesso do Google e desta nova geração. Basta observar o êxito de MySpace, Skype, YouTube, Facebook, Flickr ou Twitter, por exemplo, que levam um grande contingente de usuários a se tornarem atores, dispondo de mecanismos simples e claros para a possibilidade de estabelecerem relações.

Os autores também apresentam evidências sobre o que os jovens mais apreciam na Internet e as redes de relacionamento social. Para os jovens, a web é, ao mesmo tempo, a ferramenta social e o espaço onde as relações ocorrem, como o MySpace, por exemplo - site simbólico elaborado por e para os jovens.

No capítulo seguinte, sobre a dinâmica relacional, comenta-se sobre a flexibilidade da plataforma de fácil apropriação, além de uma nova capacidade de comunicar-se "num mundo à parte", com um maior número de pessoas e de forma livre: uma tecnologia que, a partir de 2004, ficou à disposição dos "webatores" que começaram a se servir dela de maneira mais intensa.

O livro enfatiza o tempo que os jovens passam na Internet, trocando e-mails, e que isso não afeta as suas relações pessoais, ou seja, quanto mais tempo passam enviando $e$ mails, mais tempo lidam com as pessoas. As relações alimentam as relações, eis aí a dinâmica relacional de que trataram os autores.

O capítulo 3, "As técnicas discretas da web", vem relatar sobre a tecnologia de hoje e como ela é acessível a todos.

\footnotetext{
${ }^{1}$ Pisani, Francis \& Piotet, Dominique. Como a web transforma o mundo: a alquimia das multidões. São Paulo: Senac, 2010, 304 páginas.
}

Como criar um site na web ou como criar um blog tornou-se uma tarefa muito simples; assim, a tecnologia se apresenta de forma discreta e quase desaparece por trás de simples interfaces, o que facilitou obter um maior número de usuários.

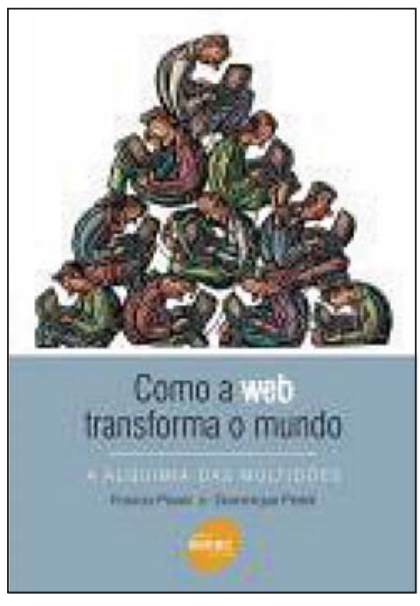

A segunda parte do livro trata da alquimia das multidões. Os autores dissertaram sobre como os "webatores" contam com um sistema novo de organização, a Folksonomia: uma forma de amontoados que se desenvolvem como organismos vivos e não pertencem a ninguém. A craigslist.org, por exemplo, foi criada pelo engenheiro programador da Charles Newmark, que começou com um simples mailing list gratuito em 1977. Ainda destacaram que a web promove oportunidades ao usuário num processo aberto sobre o qual se pode agir, proporcionando, assim, o pleno exercício da cidadania digital.

$\mathrm{Na}$ terceira parte do livro, os autores teceram considerações sobre as relações sociais e suas mídias. Eles ressaltaram que a Internet não altera somente as vidas dos indivíduos em geral, como revoluciona também o comércio e a cultura diante de todos. Assim, as implicações econômicas são bastante consideráveis, pois é possível vender mais produtos, durante mais tempo e para maior número de pessoas.

O posfácio é de Antoine Sire, diretor de marca de comunicação e de qualidade do BNP Paribas, que finaliza com discussões sobre as impressões que a Internet causa nas pessoas hoje, ou seja, os indivíduos não estão mais tão sozinhos; sua porta já não está trancada e reservada a um pequeno grupo de amigos, que compartilham de suas crenças: a maneira de viver permite a aplicação da inteligência coletiva.

Como a web transforma o mundo, do original Commentle web change le monde: l'alchimie des multitudes, é sem dúvida um livro para ser lido, consultado e discutido por todos aqueles que se sentem jovens o bastante para participar de alguma forma dos encontros promovidos na web, além de todos os interessados em como a web está transformando o mundo. Apresenta-se de uma maneira didática, dividindo-se em assuntos não apenas sobre sites, mas também voltados aos agentes modificadores, coautores da interação na web, o que facilita o entendimento do conteúdo para leigos ou profissionais. 